\title{
Quality assessment and acceptability of whiteleg shrimp (Litopenaeus vannamei) using biochemical parameters
}

\author{
So-Hyun Kim, Eun-Ju Jung, Dong-Lee Hong, Seung-Eun Lee, Yang-Bong Lee, Sueng-mok Cho and \\ Seon-Bong Kim* ${ }^{*}$ (i)
}

\begin{abstract}
Background: This study aimed to provide a basic standard for assessing freshness and acceptability of whiteleg shrimp (Litopenaeus vannamei).

Methods: It was divided into whole body and meat and stored at $25^{\circ} \mathrm{C}$ to evaluate both quality and freshness changes that occur over time. The shelf life of shrimp was estimated as 17 and $20 \mathrm{~h}$ for whole body and meat, respectively.

Results: In chemical analysis, K-value increased from 9.96 to $12.32 \%$ to a maximum of $75.14 \%$, and TVB-N increased from $1.86 \mathrm{mg} / 100 \mathrm{~g}$ to $34.71 \mathrm{mg} / 100 \mathrm{~g}$. For volatile sulfur compounds, methyl mercaptan and dimethyl disulfide increased from $0.00 \mathrm{mg} / 100 \mathrm{~g}$ to $1.10 \mathrm{mg} / 100 \mathrm{~g}$ and $1.26 \mathrm{mg} / 100 \mathrm{~g}$, respectively, rapidly increasing with decreasing freshness.
\end{abstract}

Conclusion: Changes in all biochemical indicators significantly correlated with the sensory evaluation results. This study contributes to the knowledge about whiteleg shrimp spoilage and freshness, providing a basis for developing methods to improve shrimp quality control and management.

Keywords: Whiteleg shrimp, Quality, Freshness, Sensory, Volatile compounds

\section{Background}

Whiteleg shrimp (Litopenaeus vannamei) is an important cultured species, accounting for more than $53 \%$ of the total production of farmed crustaceans (FAO 2018), and their production and consumption are increasing notably every year. Shrimps are considered perishable due to easy loss of freshness during storage and distribution, especially when transported with the viscera intact. Various enzymatic and bacterial activities occur in the shrimp during storage and distribution, leading to spoilage accompanied by the production of unpleasant odor, discoloration, and chemical changes in the meat ( $\mathrm{Du}$ et al. 2015; Ginson et al. 2013). The

\footnotetext{
* Correspondence: owlkim@pknu.ac.kr

Department of Food Science and Technology, Pukyong National University,
} Busan 48513, South Korea

\section{BMC}

production of unpleasant odor, occurrence of black spots, and meat softening are principal sensory and biochemical quality index features due to their close correlations with decreases in freshness $(\mathrm{Du}$ et al. 2015). Unpleasant odor is known to be caused by aldehydes, ketones, trimethylamine, ammonia, and volatile sulfur compounds produced by degradation of lipids and proteins by microorganisms (Ocaño-Higuera et al. 2011; Tsironi et al. 2009; Du et al. 2015; Jaffrès et al. 2011). Black spots occur mostly due to discoloration, which is a defect caused by the activity of tyrosinase during storage (Mu et al. 2012; Tsironi et al. 2009). The decomposition and softening of meat due to a rapid freshness drop is a result of protein degradation caused by microorganisms (Dai et al. 2016).

Freshness is directly related to the value of a commodity, and thus it is crucial to evaluate it promptly.

(c) The Author(s). 2020 Open Access This article is licensed under a Creative Commons Attribution 4.0 International License, which permits use, sharing, adaptation, distribution and reproduction in any medium or format, as long as you give appropriate credit to the original author(s) and the source, provide a link to the Creative Commons licence, and indicate if changes were made. The images or other third party material in this article are included in the article's Creative Commons licence, unless indicated otherwise in a credit line to the material. If material is not included in the article's Creative Commons licence and your intended use is not permitted by statutory regulation or exceeds the permitted use, you will need to obtain permission directly from the copyright holder. To view a copy of this licence, visit http://creativecommons.org/licenses/by/4.0/. 
Sensory evaluation is the most important method for determining the freshness and quality of aquatic products (Sant'Ana et al. 2011; Cardenas Bonilla et al. 2007; Alasalvar et al. 2001). However, the disadvantage of sensory evaluation is its lack of objectiveness. Therefore, chemical methods based on scientific procedures have been used coupled with a sensory method as an effective multimodal way of quality evaluation. Several studies have been conducted on freshness and quality changes of shrimp during storage. Le et al. (2017) studied changes in chemical indicators such as total volatile basic nitrogen (TVB-N), trimethylamine (TMA), and histamine by storing black tiger shrimp (Penaeus monodon) at $0{ }^{\circ} \mathrm{C}$. Huang et al. (2012) analyzed the quality of chitosan-based edible coatings of whiteleg shrimp (L. vannamei), while storing at $0{ }^{\circ} \mathrm{C}$. Tsironi et al. (2009) reported the shelf life of frozen shrimp at variable temperature conditions. Jeyasekaran et al. (2006) analyzed sensory test results, $\mathrm{pH}$, and bacteriological amount during storage of Indian white shrimp (Penaeus indicus) in dry ice. Ginson et al. (2013) analyzed changes in $K$-value and sensory acceptability of high-pressure-processed Indian white shrimp (Fenneropenaeus indicus). Nirmal and Benjakul (2009) reported the effect of ferulic acid on polyphenol oxidase and quality changes of white shrimp during iced storage. Iu et al. (2011) performed sensory evaluation and assessed TVB-N, TMA, and microbiological changes during the accelerated storage period of Acetes chinensis. Gonçalves et al. (2015) evaluated spiny lobster (Panulirus argus) using a quality index method, microbiological test, and TMA. As described above, most of the studies on guidance for aquatic products focused on sensory evaluation and/or chemical methods such as TVB-N, TMA, and $K$-value. Thus, studies on the changes in volatile nitrogen compounds (dimethylamine, ammonia) and volatile sulfur compounds (hydrogen sulfide, methyl mercaptan, dimethyl sulfide, and dimethyl disulfide) for aquatic products are scarce.

This study aimed to provide a basic standard for assessing freshness and acceptability by sensory evaluation as well as evaluation changes in biochemical indicators ( $K$-value, TVB-N, volatile nitrogen compounds, and volatile sulfur compounds) during the storage of whiteleg shrimp at ambient temperature.

\section{Materials and methods}

\section{Materials and sample preparation}

Fresh whiteleg shrimp (L. vannamei) each of approximately $24 \pm 2 \mathrm{~g}$ in weight and $17 \pm 2 \mathrm{~cm}$ in length were purchased from a local aquatic products market in Busan of Korea. The shrimp were kept in seawater with ice and were transferred to the laboratory within $2 \mathrm{~h}$. After shrimp with signs of visual defect or breakage were removed, the remaining shrimp were picked out. The shrimp were washed clean with tap water and divided into two samples, whole body and meat. The meat sample was collected immediately by hand with gloves to prevent contamination. Shrimp whole body and meat were divided into ten and stored in several sampling bags at $-4{ }^{\circ} \mathrm{C}$ until the sensory and biochemical experiments were conducted. All experiments were performed 3 times using more than five shrimps each time.

\section{Sensory evaluation}

Sensory evaluation and overall acceptability of whole body and meat of whiteleg shrimp were assessed by twenty trained panelists on a 5-point (5 for excellent, 4 for good, 3 for fair, 2 for poor, 1 for unfit) scale. Panelists were trained using discriminative tests with practice evaluation methods to identify spoilage characteristics in shrimp. Prior to conducting the different analyses, preliminary experiments and observations were conducted based on the storage period to set the evaluation parameters and criteria, which were expected to have a great influence on the organoleptic freshness of the samples. Quality evaluation parameters selected were indicators of odor, shell color, black spot, state of internal organs, adhesion of head and body, meat firmness, and meat color. The shrimp were stored at $25{ }^{\circ} \mathrm{C}$ in an incubator, and the sensory evaluation was carried out every hour from initial storage. The parameters of sensory evaluation were odor, shell color, black spot, state of internal organs, adhesion of head and body, meat firmness, and meat color, which were expected to be significantly influenced by the freshness of the shrimp. The mean of the scores given by the 20 panelists represented the overall sensory quality of the shrimp (Table 1).

\section{Measurement of $K$-value}

$K$-value was measured according to the method of Shin et al. (2013). Ten grams of the sample for each storage time was weighed and ground. Then, $20 \mathrm{~mL}$ of $10 \%$ perchloric acid was added, and the mixture was stirred for $30 \mathrm{~min}$ and then centrifuged at $3000 \mathrm{rpm}$ for $10 \mathrm{~min}$ at $4{ }^{\circ} \mathrm{C}$ to collect as much supernatant as possible; this was repeated three times. The supernatant was mixed thoroughly and adjusted to $\mathrm{pH} 6.5$ with the refrigerated $5 \mathrm{~N} \mathrm{KOH}$, and a final volume of $100 \mathrm{~mL}$ was drawn. After the solution was allowed to stand for $30 \mathrm{~min}$, the supernatant was taken out, filtered $(0.25 \mu \mathrm{m}$ membrane filter), and poured into a $1.5-\mathrm{mL}$ vial. The filtrate was analyzed by HPLC (Hitachi L-2000, Hitachi, Tokyo, Japan) with a C18 column $(3.9 \times 300 \mathrm{~mm}, 10 \mu \mathrm{m}$, Waters, Dublin, Ireland). The injection volume was $20 \mu \mathrm{L}$, the temperature was maintained at $40{ }^{\circ} \mathrm{C}$, and 
Table 1 Sensory results for each grade of whole body and meat of whiteleg shrimp (Litopenaeus vannamei) stored at $25^{\circ} \mathrm{C}$

\begin{tabular}{|c|c|c|}
\hline $\begin{array}{l}\text { Quality } \\
\text { parameters }\end{array}$ & Description & Scores \\
\hline \multirow[t]{5}{*}{ Odor ${ }^{1,2)}$} & Full freshness & 5 \\
\hline & Little freshness & 4 \\
\hline & Loss of freshness & 3 \\
\hline & $\begin{array}{l}\text { Strong ammonia and sulfur } \\
\text { compounds, fishy smell }\end{array}$ & 2 \\
\hline & $\begin{array}{l}\text { Very strong ammonia and sulfur } \\
\text { compounds }\end{array}$ & 1 \\
\hline \multirow[t]{5}{*}{ Shell color ${ }^{1)}$} & Overall unique light gray & 5 \\
\hline & $\begin{array}{l}\text { Light gray in body and light scarlet } \\
\text { in tail }\end{array}$ & 4 \\
\hline & Pink in head and tail & 3 \\
\hline & Overall red & 2 \\
\hline & Overall red, dark red in head & 1 \\
\hline \multirow[t]{5}{*}{ Black spot ${ }^{1)}$} & Absent & 5 \\
\hline & Few black spots & 4 \\
\hline & Some black spots on head and tail & 3 \\
\hline & Black spots on head and tail & 2 \\
\hline & Very noticeable black spots & 1 \\
\hline \multirow{5}{*}{$\begin{array}{l}\text { Adhesion of head } \\
\text { and body }{ }^{1)}\end{array}$} & Strong adherence & 5 \\
\hline & Good adherence & 4 \\
\hline & Weak adherence & 3 \\
\hline & Easy separation with weak force & 2 \\
\hline & Separated by itself when raised & 1 \\
\hline \multirow[t]{5}{*}{ Internal organs ${ }^{1)}$} & Scarlet and excellent adhesion & 5 \\
\hline & Scarlet and optimum adhesion & 4 \\
\hline & Red and fair adhesion & 3 \\
\hline & Red and flow down & 2 \\
\hline & Dark red and empty head & 1 \\
\hline \multirow{5}{*}{$\begin{array}{l}\text { Meat elasticity and } \\
\text { firmness }\end{array}$} & Very strong elasticity, rigid, and firm & 5 \\
\hline & Strong elasticity, rigid & 4 \\
\hline & $\begin{array}{l}\text { Relatively good elasticity, beginning } \\
\text { to soften }\end{array}$ & 3 \\
\hline & Low elasticity and quite soft & 2 \\
\hline & $\begin{array}{l}\text { Lost elasticity, easily breaks down } \\
\text { by weak force }\end{array}$ & 1 \\
\hline \multirow[t]{5}{*}{ Meat color ${ }^{1,2)}$} & Translucent light gray, shiny & 5 \\
\hline & $\begin{array}{l}\text { Translucent light gray and scarlet tail, } \\
\text { less intense gloss }\end{array}$ & 4 \\
\hline & Opaque and milky, losing luster & 3 \\
\hline & Overall pink & 2 \\
\hline & Overall red & 1 \\
\hline
\end{tabular}

${ }^{1)}$ Only for whole body

${ }^{1,2)}$ For both whole body and meat the flow rate was $0.8 \mathrm{~mL} / \mathrm{min}$. The mobile phase was $1 \%$ triethylamine-perchloric acid, and a UV detector was used at $254 \mathrm{~nm}$. All standard materials were purchased from Sigma-Aldrich Korea, and the amounts of each ATP and its related compounds were determined and calculated based on the standard ATP, ADP, AMP, IMP, inosine (HxR), and hypoxanthine $(\mathrm{Hx})$.

\section{Measurement of total volatile basic nitrogen (TVB-N)}

Ten grams of the sample was put into $50 \mathrm{~mL}$ of distilled water, homogenized with a stirrer (MSH-30A, Daihan Scientific, Gangwon-do, Korea) and filtered (Whatman no. 1). The filtrate was adjusted to be slightly acidic $(\mathrm{pH}$ 4.5-5.5) with 5\% sulfuric acid solution and diluted to $100 \mathrm{~mL}$ with distilled water. One milliliter of the filtrate was placed in a Conway unit and measured according to the Conway microdiffusion method (Conway 1947).

\section{Determination of trimethylamine, dimethylamine, and ammonia}

Samples of each $500 \mathrm{~g}$ were weighed, ground, and sealed in an aluminum gas bag $(265 \times 212.5 \mathrm{~mm}$, As One, Osaka, Japan), which was placed in a drying oven at 50 ${ }^{\circ} \mathrm{C}$ for $30 \mathrm{~min}$. The generated headspace gas was directly injected into a gas chromatography-nitrogen phosphorus detector (GC-NPD) using a gas tight syringe, to analyze dimethylamine (DMA) and trimethylamine (TMA). The GC-NPD was used to conduct a quantitative analysis, and the RTX-35 AMINE $(30.0 \mathrm{~m} \times 0.53 \mathrm{~mm} \times 1 \mu \mathrm{m}$, Restek, Bellefonte, PA, USA) was used as a capillary column. The optimized oven temperature program was initially $50{ }^{\circ} \mathrm{C}$ for $10 \mathrm{~min}$ and increased at a rate of 10 ${ }^{\circ} \mathrm{C} / \mathrm{min}$ until it reached $150{ }^{\circ} \mathrm{C}$, where it was held for 20 $\mathrm{min}$. The operating temperatures of the injector and the detector were each $250{ }^{\circ} \mathrm{C}$. Helium was used at $6.5 \mathrm{~mL} /$ min as a carrier gas. For NPD, hydrogen and air were used at $27 \mathrm{~mL} / \mathrm{min}$ and $275.5 \mathrm{~mL} / \mathrm{min}$, respectively. Ammonia measurement was performed by directly injecting headspace gas collected using the same procedure as in TMA and DMA detection into an ammonia gas detection tube (Gas Tec, Kanagawa, Japan).

\section{Determination of volatile sulfur compounds}

Volatile sulfur compounds were measured according to the method of Mahattanatawee and Rouseff (2014) with some modifications. The volatile sulfur compounds were analyzed by GC-PFPD (GC-2010, Shimadzu, Kyoto, Japan), by directly injecting headspace gas using the same procedure as in TMA and DMA detection. The oven temperature program of GC consisted of an initial temperature of $35^{\circ} \mathrm{C}$ for $15 \mathrm{~min}$ and was increased at $5{ }^{\circ} \mathrm{C} / \mathrm{min}$ until it reached $100{ }^{\circ} \mathrm{C}$, where it was held for $1 \mathrm{~min}$. The column used was DB$1(30.0 \mathrm{~m} \times 0.25 \mathrm{~mm} \times 0.28 \mu \mathrm{m}$, Agilent Technologies, 
Stevens Creek Blvd, Santa Clara, USA). The condition of carrier and detector gases was identical to that in the TMA and DMA analyses with GC-NPD. Injector and detector temperatures were $200{ }^{\circ} \mathrm{C}$ and $360{ }^{\circ} \mathrm{C}$, respectively.

\section{Statistical analyses}

The results of the experiment were statistically processed using SAS 9.4 (SAS, 2017). The differences between sample groups were analyzed using the ANOVA test and Duncan's multiple range test $(p<0.05)$.

\section{Results and discussion}

\section{Sensory evaluation}

Figure 1 shows the overall sensory scores according to the quality parameters and description of whiteleg shrimp; scores range from 5 (best quality) to 1 (worst quality). Whiteleg shrimp exhibited a significant quality decline during storage at ambient temperature. At initial storage, fresh shrimp exhibited fresh odor in both whole body and meat, with a sensory score of 5 . After storage for $7 \mathrm{~h}$, the whole body manifested a decrease in quality, with a sensory score of 3 . After storage for $17 \mathrm{~h}$, the whole body sample exhibited an offensive ammoniacal and strong sulfur compound odor, with a sensory score of 1 . After $20 \mathrm{~h}$ of storage, the shrimp had a strong smell of ammonia and volatile sulfur compounds. According to $\mathrm{Du}$ et al. (2015), shrimp produces an unpleasant odor as its quality changes. In our study, the first sensory changes that occurred in the stored shrimp were related to odor and appearance.
The initial shell color of the shrimp was light gray. After $13 \mathrm{~h}$ of storage, the whole body of the shrimp from the tail to head portion changed to pink and then to red color, with a sensory score of 2 , and after $17 \mathrm{~h}$, the shell color was reddish, with a sensory score of 1 . When astaxanthin is in a state of binding with proteins, it has a blue-green color (alive), but becomes darker when it is released due to protein denaturation (Higuera-Clapara et al. 2006). Fresh shrimp did not show black spots. However, after $7 \mathrm{~h}$, black spots appeared partially on the head and tail, resulting in a score of 3 . After $17 \mathrm{~h}$, black spots were remarkable, with a score of 1 . Black spots in shrimp are caused by production of melanin by tyrosinase and the effect of hemocyanin ( $\mathrm{Mu}$ et al. 2012; Jang et al. 2003; Huang et al. 2012). This change in shrimp is thus called melanosis and occurs if shrimp are improperly stored after harvest.

Initially, the head and the body of fresh shrimp maintained a firm connection, but once the freshness decreased, the head was loosened and slightly detached from the body. After storage for $17 \mathrm{~h}$, the adhesion force became weak, and the head and body were easily separated. Fresh internal organs of the shrimp had a scarlet color, with a strongly adhered head. After $13 \mathrm{~h}$ of storage, shrimp changed to a red color and their internal organs turned to liquid and flowed downward, with a sensory score of 2 . After $17 \mathrm{~h}$, the internal organs were dark red, with a score of 1 . The fresh shrimp had a very strong elasticity, being rigid and firm, but the elasticity of the meat lessened and the meat softened as the freshness decreased. After $17 \mathrm{~h}$, the shrimp lost elasticity and were easily broken down by a relatively small force.

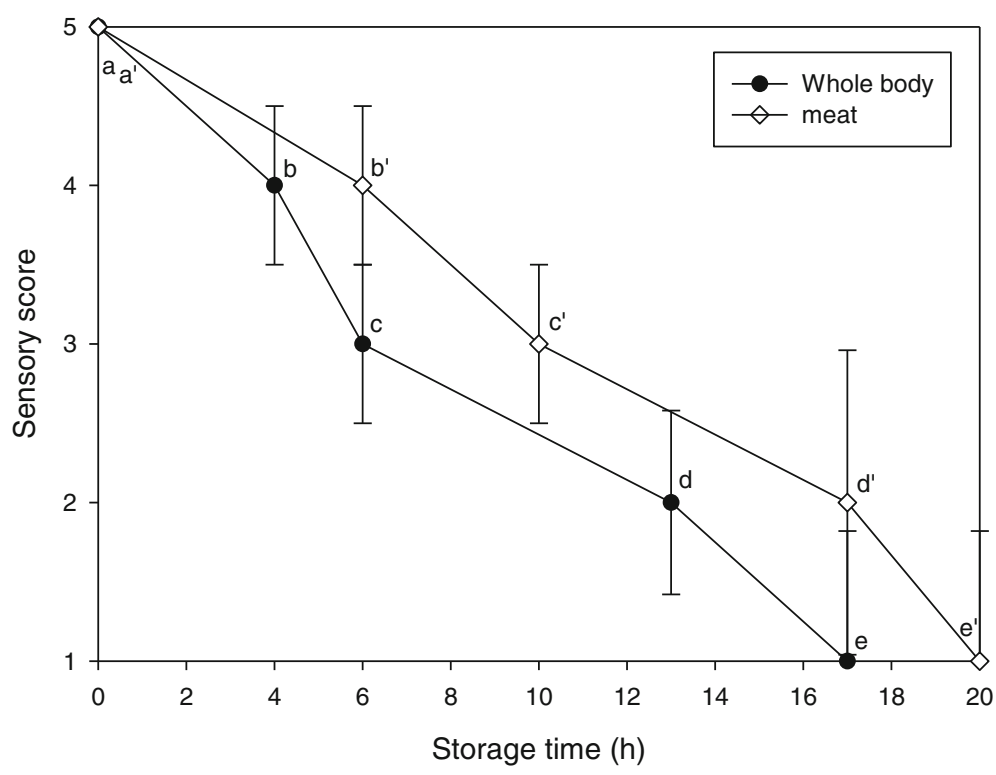

Fig. 1 Changes in sensory quality of whiteleg shrimp (Litopenaeus vannamei) during storage at $25^{\circ} \mathrm{C}$ 
Fresh shrimp meat was light gray in color, but the gloss of spoiled meat decreased and the color of the body (from tail to head) changed from pinkish to reddish. The whole body and meat of the shrimp exhibited an overall red color after 17 and $20 \mathrm{~h}$, respectively. All the parameters were considered useful to distinguish the freshness of the whiteleg shrimp. However, the parameter changes could be irregular depending on how the whiteleg shrimp was stored. Similarly, Iu et al. (2011) reported that color and odor for dried Acetes chinensis changed significantly during storage. Tsironi et al. (2009) observed changes in frozen shrimp appearance, odor, and color during storage. Jeyasekaran et al. (2006) found changes in odor, color, and texture in sensory evaluation of frozen shrimp that were similar to the results of this study.

\section{K-value}

Figure 2 shows the changes in $K$-value depending on the storage time of the whole body and meat of whiteleg shrimp. Whole body of the fresh shrimp showed $K$ values of $9.96-12.32 \%$ (4-5 points), fair-quality shrimp exhibited a $K$-value of $18.14 \%$ (3 points), and poorquality shrimp exhibited a $K$-value of $50.83 \%$ (2 points, after $13 \mathrm{~h}$ of storage). $K$-value of shrimp meat increased more slowly than did that of the whole body throughout the storage period. Meat showed a $K$-value of $9.46 \%$ when fresh, which increased to $29.70 \%$ at 3 points after $7 \mathrm{~h}$ of storage; poor-quality shrimp exhibited a $K$-value of $58.97 \%$ ( 2 points, after $17 \mathrm{~h}$ of storage) and $75.14 \%$ at 1 point after $20 \mathrm{~h}$ of storage. $K$-value is a relative proportion used to assess ATP of degradation products, and it is used as an index to determine freshness through initial change of nucleotides in aquatic products (Ólafsdóttir et al. 1997). However, the rate of nucleotide degradation, processing method, and storage conditions differ by species (Ginson et al. 2013). Saito et al. (1959) described fishery products with $K$-values lower than $20 \%$ as very fresh, those with less than $50 \%$ as moderately fresh, and those with higher than $70 \%$ as unfresh. This is similar to our results, which indicated that products with $\mathrm{K}$-values of less than $20 \%$ are fresh and those with Kvalue of $50-70 \%$ are unfresh. In addition, similar to our results, Ocaño-Higuera et al. (2011) reported that $K$ value has a direct linear relationship with storage time, and thus can be used as a useful indicator for monitoring loss of freshness. Alasalvar et al. (2001) reported that sensory score of fish showed good agreement with $K$ value results throughout the storage period. Therefore, $K$-value analysis is considered to have a significant correlation with the sensory evaluation. Like other seafoods, $K$-value analysis can be a useful indicator for evaluating the freshness of whiteleg shrimp.

\section{TVB-N}

TVB-N includes measurement of TMA, DMA, ammonia, and other nitrogen compounds associated with seafood spoilage and increases as spoilage progresses (Ocaño-Higuera et al. 2011). Figure 3 shows the change in TVB-N depending on the storage time and condition of the whole body and meat of whiteleg shrimp. For the whole body, TVB-N levels of (5-4 points) $1.86-10.60 \mathrm{mg} /$

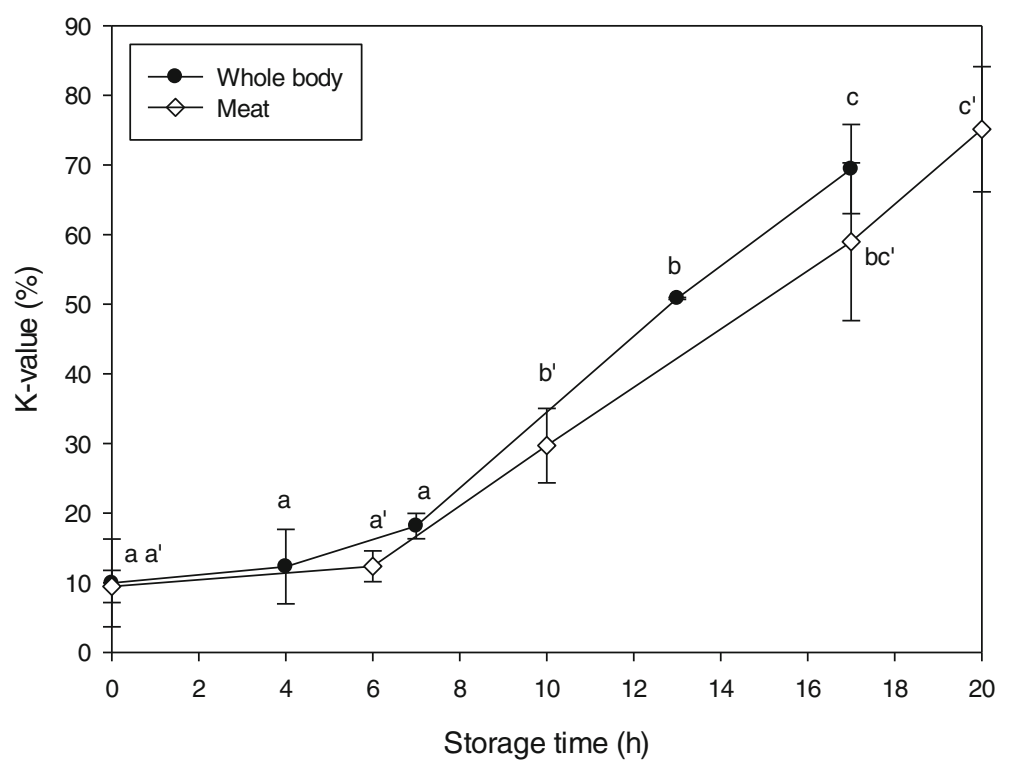

Fig. 2 Changes in K-value in whole body and meat of whiteleg shrimp (Litopenaeus vannamei) during storage at $25^{\circ} \mathrm{C}$. Measured values are the average of three analyses \pm standard deviation. (a)-(e) The differences with different superscript letters in the same column are significant at the 0.05 level for multiple comparisons of least square difference 


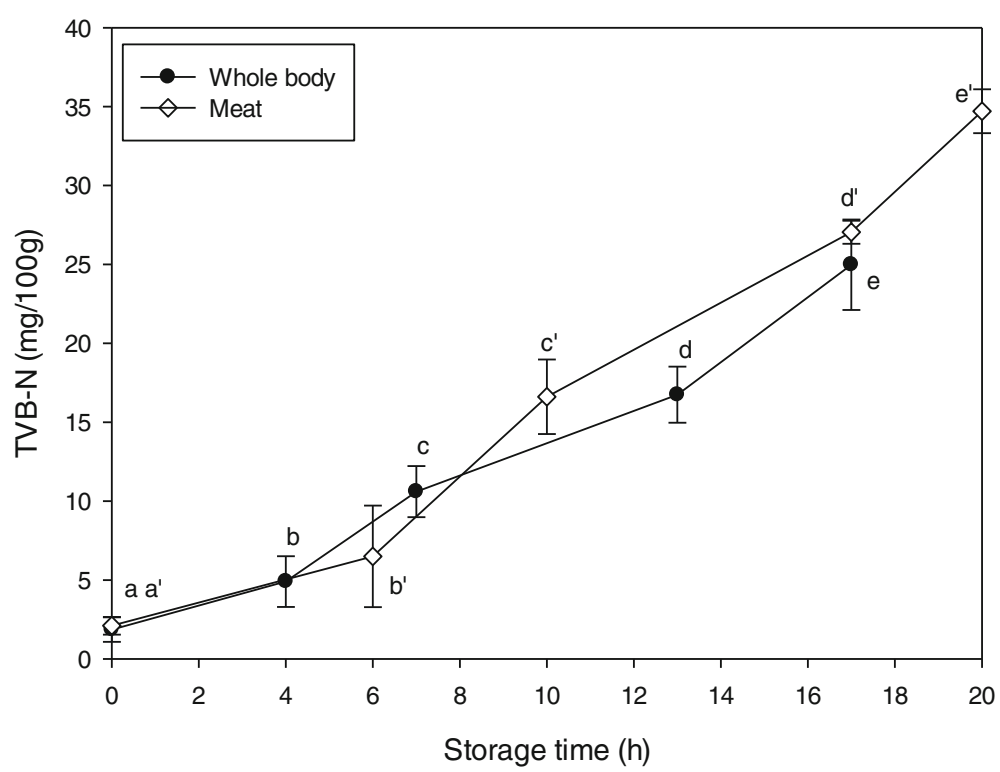

Fig. 3 Changes in TVB-N of whole body and meat of whiteleg shrimp (Litopenaeus vannamei) during storage at $25^{\circ} \mathrm{C}$. Measured values are average of three analyses \pm standard deviation. (a)-(e) The differences with different superscript letters in the same column are significant at the 0.05 level for multiple comparisons of least square difference

$100 \mathrm{~g}, 10.60 \mathrm{mg} / 100 \mathrm{~g}, 16.74 \mathrm{mg} / 100 \mathrm{~g}$, and $24.98 \mathrm{mg} / 100$ g indicated fresh (5-4 points), fair (3 points), poor quality ( 2 points, storage for $13 \mathrm{~h}$ ), and unfit (1 point, storage for $17 \mathrm{~h}$ ), respectively. Shrimp meat samples showed a similar tendency during the storage period. In general, TVB-N levels are applied to determine the freshness of fish. Fish decomposition is a progressive proteolysis of the muscle tissue induced primarily by the action of microorganisms and, to a minor extent, autolytic enzymes (Ocaño-Higuera et al. 2011). In fish, the standard is known to be $5-10 \mathrm{mg} /$ $100 \mathrm{~g}$ for fresh fish, $15-25 \mathrm{mg} / 100 \mathrm{~g}$ for normal fresh, 30$40 \mathrm{mg} / 100 \mathrm{~g}$ for initial spoilage, and $50 \mathrm{mg} / 100 \mathrm{~g}$ or more for spoilt fish (Özyurt et al. 2007). However, this standard cannot be applied to sharks or stingrays because they contain a large amount of urea or TMAO and generate a large amount of ammonia, TMA, and DMA (Jo et al. 2013). Increases in these parameters during storage have been observed in many studies. Dai et al. (2016) measured TVB-N changes by shrimp (Metapenaeus ensis) storage at $4{ }^{\circ} \mathrm{C}$. Lee and Um (1995) reported that TVB-N increased from initial $5 \mathrm{mg} / 100 \mathrm{~g}$ to $14.8 \mathrm{mg} / 100 \mathrm{~g}$ after 8 months by storing shrimp (Penaeus japonicus) at $-18{ }^{\circ} \mathrm{C}$. In fact, based on the results of TVB-N values and sensory evaluation, the biochemical freshness standards for whiteleg shrimp are slightly lower than the standards used in fish.

\section{Volatile nitrogen compounds}

Volatile nitrogen compounds such as TMA, DMA, and ammonia are produced as a result of freshness degradation of aquatic products and affect the sensory quality of those products. TMA is a typical fishy odor component produced by trimethylamine oxide (TMAO) due to bacterial action and is also occasionally present in fresh meat (Ólafsdóttir et al. 1997). DMA is produced by the degradation of TMAO and the decomposition of amino acids, and ammonia is mainly produced by the decomposition of amino acids due to the action of bacteria (Huss. 1995). Among these volatile nitrogen compounds, TMA is occasionally used as a freshness judgment criterion for fish. The TMA value for the initial decomposition baseline in fish is well known to be 3 $\mathrm{mg} / 100 \mathrm{~g}$ (Song et al. 2005). Figure 4 shows changes in the content of volatile nitrogen compounds (TMA, DMA, and ammonia) during storage of whole body and meat of whiteleg shrimp. Under TMA analysis, the whole body showed a low value of $0.67-0.88 \mathrm{mg} / 100 \mathrm{~g}$ at the initial fresh status (5-4 points), while the fair-quality whole body ( 3 points after $7 \mathrm{~h}$ storage) had a value of $1.69 \mathrm{mg} / 100 \mathrm{~g}$. The TMA value of the whole body was $2.16 \mathrm{mg} / 100 \mathrm{~g}$ or more when in poor quality (less than 2 points, after $13 \mathrm{~h}$ of storage). The TMA value of meat was slightly lower than that of the whole body at the fresh stage but was similar to that of whole body at the poor quality stage (less than 2 points, after $17 \mathrm{~h}$ of storage).

In a previous study, Okpala et al. (2014) reported a significant increase in TMA values during iced storage of Pacific white shrimp. Iu et al. (2011) reported that the TMA value increased from an initial $7.93 \mathrm{mg} / 100 \mathrm{~g}$ to $16.06 \mathrm{mg} / 100 \mathrm{~g}$ after 14 days of shrimp storage at $37^{\circ} \mathrm{C}$. TMA levels of Acetes chinensis in our study showed a similar trend to the results obtained by Le et al. (2017). 
A

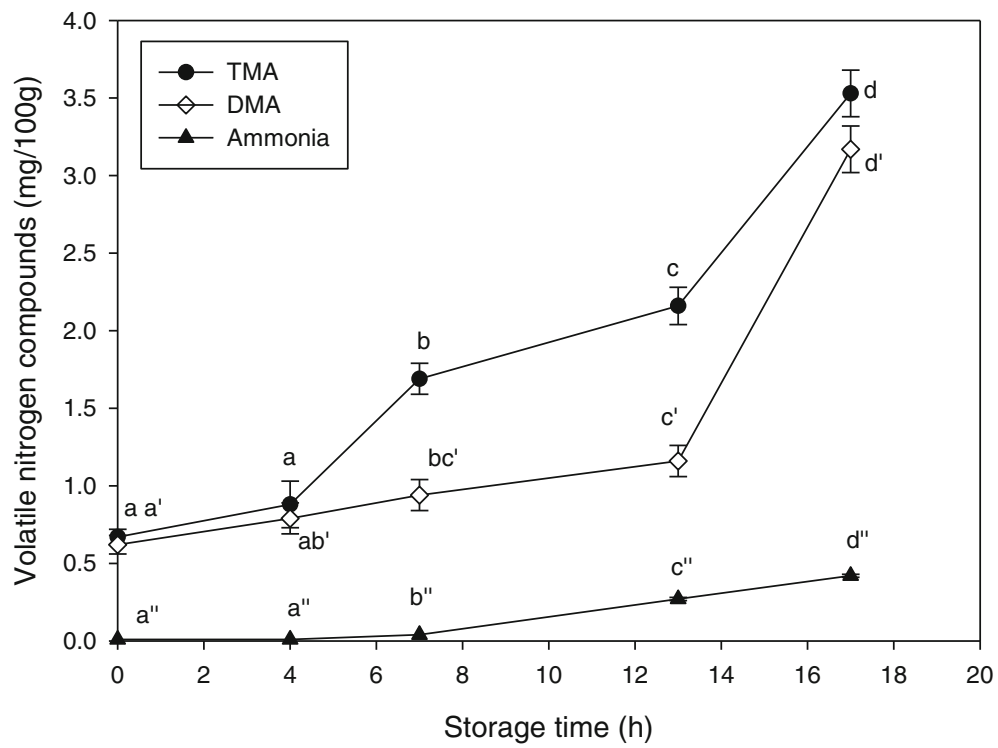

B

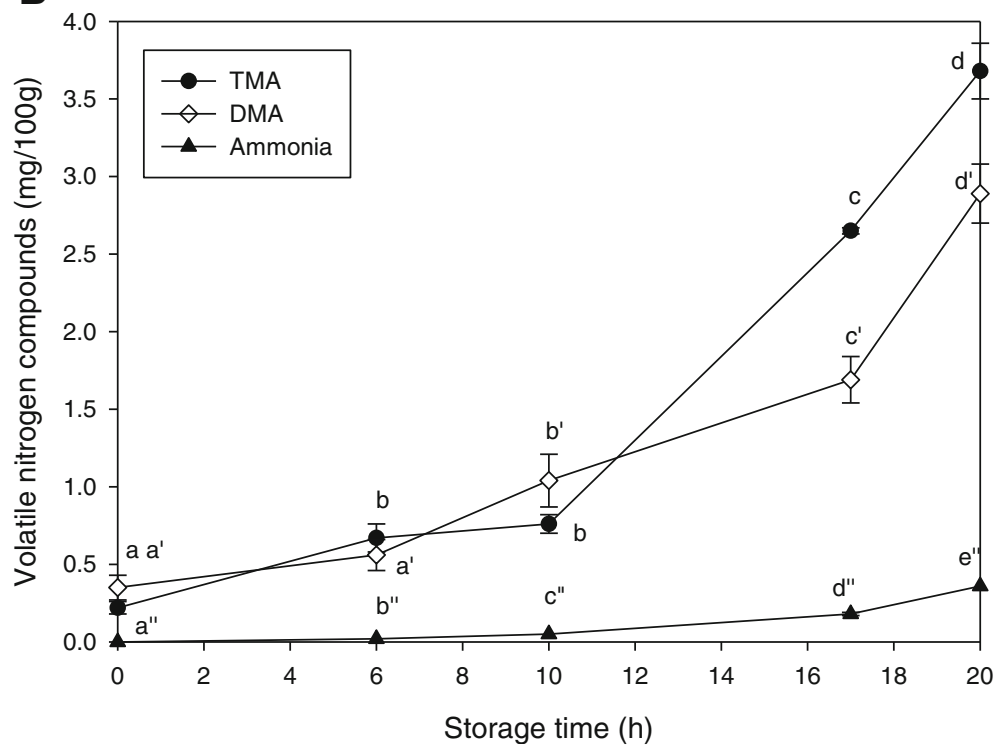

Fig. 4 Changes in volatile nitrogen compounds in whole body (a) and meat (b) of whiteleg shrimp (Litopenaeus vannamei) during storage at $25^{\circ} \mathrm{C}$. Measured values are the average of three analyses \pm standard deviation. (a-e) The differences with the different superscript letters in the same column are significant at the 0.05 level for multiple comparison of least square difference. TMA and DMA means trimethylamine and dimethylamine, respectively

DMA values for the whole body fresh shrimp (5-4 points) were $0.62-0.79 \mathrm{mg} / 100 \mathrm{~g}$ during the storage period, while the values for the poor-quality shrimp (less than 2 points, after $13 \mathrm{~h}$ of storage) were increased more than $1.16 \mathrm{mg} / 100 \mathrm{~g}$. For the unfit sample (1 point, after $17 \mathrm{~h}$ of storage), the DMA value was $3.17 \mathrm{mg} / 100 \mathrm{~g}$. DMA of the meat was slightly lower than that of the whole body. Ammonia measurement during storage showed that ammonia in the whole body was hardly produced in the fresh (5-4 points) shrimp; however, it was
$0.27 \mathrm{mg} / 100 \mathrm{~g}$ in the poor-quality shrimp ( 2 points, after $13 \mathrm{~h}$ of storage). Ammonia content of the meat was 0.18 $\mathrm{mg} / 100 \mathrm{~g}$ or more, with the meat exhibiting poor quality at 2 points after $17 \mathrm{~h}$ of storage. These results indicate that the TMA and DMA rapidly increased as quality decreased, presenting a strong correlation with the results of the sensory evaluation of freshness. Ammonia is produced less than TMA and DMA, but its lower threshold value gives it a significant effect on sensual discrimination due to spoilage. 


\section{Volatile sulfur compounds}

The degradation of sulfur-containing amino acids such as cysteine and methionine as a result of decrease in freshness can produce hydrogen sulfide and other volatile sulfur compounds (Higgins et al. 2003, Kadota et al. 1972). Figure 5a shows changes in volatile sulfur compounds by storage time of the whole body of whiteleg shrimp. The volatile sulfur compounds were not detected in the fresh shrimp (5-4 points). For normal fresh (3 points, storage for $7 \mathrm{~h}$ ), minimal amounts of hydrogen sulfide, methyl mercaptan, and dimethyl sulfide, but not dimethyl disulfide, were detected. At poor quality (2 points, storage for $13 \mathrm{~h}$ ), hydrogen sulfide $(0.34 \mathrm{mg} / 100 \mathrm{~g})$, methyl mercaptan $(0.72 \mathrm{mg} / 100 \mathrm{~g})$, and dimethyl disulfide $(0.49 \mathrm{mg} / 100 \mathrm{~g})$ were increased, including dimethyl sulfide $(0.06 \mathrm{mg} /$ $100 \mathrm{~g})$. Methyl mercaptan $(1.10 \mathrm{mg} / 100 \mathrm{~g})$ and dimethyl disulfide $(1.26 \mathrm{mg} / 100 \mathrm{~g})$ increased significantly in the

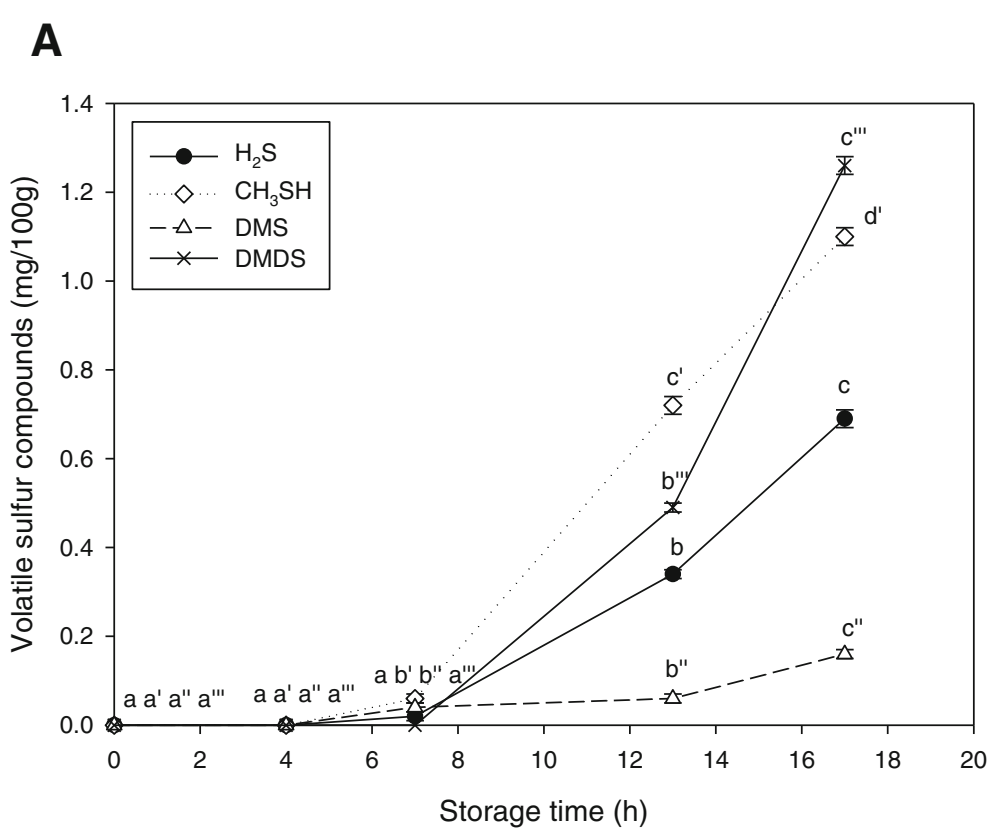

B

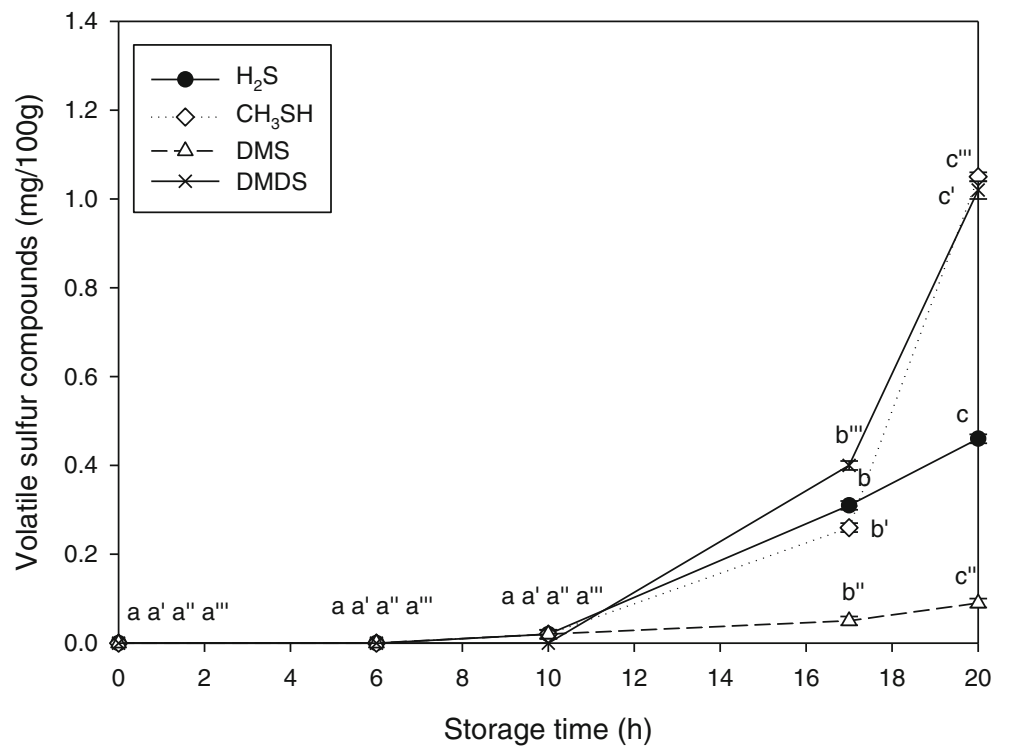

Fig. 5 Changes in volatile sulfur compounds in whole body (a) and meat (b) of whiteleg shrimp (Litopenaeus vannamei) during storage at $25^{\circ} \mathrm{C}$. Measured values are the average of three analyses \pm standard deviation. (a-e) The differences with different superscript letters in the same column are significant at the 0.05 level for multiple comparisons of least square difference. $\mathrm{H}_{2} \mathrm{~S}, \mathrm{CH}_{3} \mathrm{SH}$, DMDS, and DMS means hydrogen sulfide, methyl mercaptan, dimethyl sulfide, and dimethyl disulfide, respectively 
unfit sample ( 1 point, storage for $17 \mathrm{~h}$ ). Figure $5 \mathrm{~b}$ shows changes in volatile sulfur compounds during storage of shrimp meat at $25^{\circ} \mathrm{C}$. At this level, no volatile sulfur compounds were detected in the fresh meat of shrimp, and the content of all the volatile sulfur compounds increased as the freshness decreased. Moreover, the increase rate and amount of volatile sulfur compounds in meat were slightly lower than those in the whole body. Hydrogen sulfide is often found to be produced by sulfate-reducing bacteria during spoilage of aquatic products. Methyl mercaptan is readily oxidized to disulfides in the air, which are less volatile than hydrogen sulfide, but produce a more "off-flavor" (Kadota et al. 1972). Dimethyl sulfide is produced by enzymatic cleavage of dimethylsulfoniopropionate during the spoilage of aquatic products (Leck et al. 1990; Reisch et al. 2011). Dimethyl disulfide was reported to arise from bacterial degradation of methionine or oxidation of methanethiol (Alasalvar et al. 2005; Kadota et al. 1972). As described above, methyl mercaptan and dimethyl disulfide were increased with a decrease in freshness of whiteleg shrimp. The formation of these volatile sulfur compounds is thought to have a significant influence on freshness determination in aquatic products, along with the volatile nitrogen compounds. The reason is thought to be that these volatile sulfur compounds have low threshold values, even if they are produced in low amounts.

\section{Conclusion}

This study investigated sensory and chemical indicators to evaluate the freshness and quality changes of whiteleg shrimp with storage time. When sensory evaluation and chemical indicators were compared, all changes showed significant correlations. Among them, the most sensitive chemical changes with time were methyl mercaptan and dimethyl sulfide among the volatile sulfur compounds. This result demonstrates that DMA, volatile sulfur compounds, TVB-N, $K$-value, and TMA are useful for quality and quality change evaluation for not only crustaceans but also all aquatic products, based on this freshness assessment for whiteleg shrimp.

\footnotetext{
Abbreviations

TVB-N: Total volatile basic nitrogen; TMA: Trimethylamine; DMA: Dimethylamine; $\mathrm{KOH}$ : Potassium hydroxide; HPLC: High-performance liquid chromatography; ATP: Adenosine triphosphate; ADP: Adenosine diphosphate; AMP: Adenosine monophosphate; IMP: Inosine monophosphate; HxR: Inosine; Hx: Hypoxanthine; GC-NPD: Gas chromatography-nitrogen phosphorous detector; GC-PFPD: Gas chromatography-pulsed flame photometric detector; ANOVA: Analysis of variance
}

\section{Acknowledgements}

This research was supported by the Korea Food \& Drug Administration (KFDA).

\section{Authors' contributions}

Kim S.B., Lee Y.B., and Cho S.M designed the conceptualization and methodology of the study. Kim S.B., Lee Y.B., Cho S.M., and Kim S.H wrote and edited the manuscript. Kim S.H. and Hong D.L. conducted formal experiments. Jung E.J. and Lee S.E. contributed investigation and discussions. Kim S.B. supervised this project. All the authors critically reviewed the manuscript and approved the final version.

\section{Funding}

The design of the study; collection, analysis, and interpretation of the data; and writing of the manuscript were funded by a grant from Korea Food \& Drug Administration (KFDA)

\section{Availability of data and materials}

All datasets generated during and/or analyzed during the current study are available from the corresponding author on reasonable request.

\section{Ethics approval and consent to participate}

Not applicable.

\section{Consent for publication}

Not applicable.

\section{Competing interests}

The authors declare that they have no competing interests.

Received: 27 May 2020 Accepted: 24 July 2020

Published online: 04 September 2020

\section{References}

Alasalvar C, Taylor AKD, Shahidi F. Comparison of volatiles of cultured and wild sea bream (Sparus aurata) during storage in ice by dynamic headspace analysis/gas chromatography-mass spectrometry. J Agric Food Chem. 2005; 53(7):2616-22.

Alasalvar C, Taylor KDA, Öksüz A, Garthwaite T, Alexis MN, Grigorakis K. Freshness assessment of cultured sea bream (Sparus aurata) by chemical, physical and sensory methods. Food Chem. 2001;72(1):33-40.

Bonilla CA, Sveinsdottir K, Martinsdottir E. Development of Quality Index Method (QIM) scheme for fresh cod (Gadus morhua) fillets and application in shelf life study. Food Control. 2007;18(4):352-8.

Conway EJ. Microdiffusion analysis and volumetric error. London: Crosby Lockwood. 1947;357.

Dai Q, Cheng JH, Sun DW, Zhu Z, Pu H. Prediction of total volatile basic nitrogen contents using wavelet features from visible/near-infrared hyperspectral images of prawn (Metapenaeus ensis). Food Chem. 2016;197(15):257-65.

Du L, Chai C, Guo M, Lu X. A model for discrimination freshness of shrimp. Sens Biosensing Res. 2015;6:28-32.

FAO. The State of World Fisheries and Aquaculture. The State of World Fisheries and Aquaculture. 2018;1-83. Doi:https://doi.org/10.18356/eeca78e4-en.

Ginson J, Kamalakanth CK, Bundu J, Venkateswarlu R, Das S, Chauhan OP, Srinivasa Gopal TK. Changes in K value, microbiological and sensory acceptability of high pressure processed Indian white prawn (Fenneropenaeus indicus). Food Bioproc Tech. 2013;6(5):1175-80.

Gonçalves AA, de Lima JTAX, de Paula FER. Development of Quality Index Method (QIM) scheme for spiny lobster (Panulirus argus, Latreille, 1804) stored in ice. Food Control. 2015;47:237-45.

Higgins MJ, Yarosz DP, Chen YC, Murthy SN, Mass NA, Cooney JR. Mechanisms of volatile sulfur compound and odor production in digested biosolids. Proceedings Water Enviro Federation. 2003;1:993-805.

Higuera-Clapara I, Felix-Valenzuela L, Goycoolea FM. Astaxanthin: a review of its chemistry and applications. Crit Rev Food Sci and Nutr. 2006;46(2):185-96.

Huang J, Chen Q, Qiu M, Li S. Chitosan-based edible coatings for quality preservation of postharvest Whiteleg shrimp (Litopenaeus vannamei). J Food Sci. 2012;77(4):C491-6.

Huss HH. Quality and quality changes in fresh fish. Rome, Italy: Food and Agriculture Organization (FAO) of the United Nations. FAO Fish Tech. 1995;348.

Iu F, Zhang JY, Liu SL, Wang Y, Ding YT. Chemical, microbiological and sensory changes of dried Acetes chinensis during accelerated storage. Food Chem. 2011;127(1):159-68. 
Jaffrès E, Lalanne V, Macé S, Cornet J, Cardinal M, Sérot T, Dousset X, Joffraud J-J. Sensory characteristics of spoilage and volatile compounds associated with bacteria isolated from cooked and peeled tropical shrimps using SPME-GCMS analysis. Int J Food Microbiol. 2011;147(3):195-202.

Jang MS, Sanada A, Ushio H, Tanaka M, Ohshima T. Inhibitory effect of enokitake extract on melanosis of shrimp. Fish Sci. 2003;69(2):379-84.

Jeyasekaran G, Ganesan P, Anandaraj R, Jeya Shakila R, Sukumar D. Quantitative and qualitative studies on the bacterilolgical quality of Indian white shrimp (Penaeus indicus) stored in dry ice. Food Microbiol. 2006;23(6):526-33.

Jo HS, Kim KH, Kim MJ, Kim HJ, Jeong GS, Cha BY, Choi JD, Heu MS, Kim JS. Comparison of quality characteristics between imported Skate Rays. Korean J Fish Aquat Sci. 2013;46(3):245-51.

Kadota $\mathrm{H}$, Ishida Y. Production of volatile sulfur compounds by microorganisms. Annu Rev Microbiol. 1972;26(1):127-38.

Le NT, Doan NK, Nguyen Ba T, Tran TVT. Towards improved quality benchmarking and shelf life evaluation of black tiger shrimp (Penaeus monodon). Food Chem. 2017;235:220-6.

Leck C, Larsson U, Bågander LE, Johansson S, Hajdu S. Dimethyl sulfide in the Baltic Sea: annual variability in relation to biological activity. J Geophys Res Oceans. 1990;95(C3):3353.

Lee YC, Um YS. Quality determination of Shrimp (Penaeus japonicus) during iced and frozen storage. Korean J Food Sci Tech. 1995;27(4):520-4.

Mahattanatawee K, Rouseff RL. Comparison of aroma active and sulfur volatiles in three fragrant rice cultivars using GC-Olfactometry and GC-PFPD. Food Chem. 2014;154:1-6.

Mu H, Chen H, Fang X, Mao J, Gao H. Effect of cinnamaldehyde on melanosis and spoilage of Pacific white shrimp (Litopenaeus vannamei) during storage. Sci Food Agric. 2012;92:2177-82.

Nirmal NP, Benjakul S. Effect of ferulic acid on inhibition of polyphenoloxidase and quality changes of Pacific white shrimp (Litopenaeus vannamei) during iced storage. Food Chem. 2009;116(1):323-31.

Ocaño-Higuera VM, Maeda-Martínez AN, Marquez-Ríos E, Canizales-Rodríguez DF, Castillo-Yáñez FJ, Ruíz-Bustos E, Graciano-Verdugo AZ, Plascencia-Jatomea M. Freshness assessment of ray fish stored in ice by biochemical, chemical and physical methods. Food Chem. 2011;125(1):49-54.

Okpala COR, Choo WS, Dykes GA. Quality and shelf life assessment of Pacific white shrimp (Litopenaeus vannamei) freshly harvested and stored on ice. LWT-Food Sci Technol. 2014;55(1):110-6.

Ólafsdóttir G, Martinsdóttir E, Oehlenschlüger J, Dalgaard P, Jensen B, Undeland I, Mackie IM, Henehan G, Nielsen J, Nilsen H. Methods to evaluate fish freshness in research and industry. Trends Food Sci Technol. 1997;8(8):258-65.

Özyurt G, Özogul Y, Özyurt CE, Polat A, Özogul F, Gökbulut C, Ersoy B, Küley E. Determination of the quality parameters of pike perch Sander lucioperca caught by gillnet, longline and harpoon in Turkey. Fisher Sci. 2007;73(2):412-20.

Reisch CR, Moran MA, Whitman WB. Bacterial catabolism of dimethylsulfoniopropionate (DMSP). Front Microbiol. 2011;2:172.

Saito T, Arai K, Matsuyoshi M. A new method for estimating the freshness of fish. Nippon Suisan Gakkaishi. 1959;24(9):749-50.

Sant'Ana LS, Soares S, Vaz-Pires P. Development of a quality index method (QIM) sensory scheme and study of shelf-life of ice-stored blackspot seabream (Pagellus bogaraveo). LWT-Food Sci Technol. 2011;44(10):2253-9.

Shin $\mathrm{SH}$, Sung KH, Chung $\mathrm{CH}$. Physicochemical changes in olive flounder (Paralichthys olivaceus) muscle by iced water pre-treatment. Korean J Food Sci Technol. 2013:45(6):700-7.

Song HN, Lee DG, Han SW, Yoon HK, Hwang IK. Quality changes of salted and semi-dried mackerel fillets by UV treatment during refrigerated storage. Korean J food cook sci. 2005;21(5):662-8.

Tsironi T, Dermesonlouoglou E, Giannakourou M, Taoukis P. Shelf life modelling of frozen shrimp at variable temperature conditions. LWT-Food Sci Technol. 2009;42(2):664-71.

\section{Publisher's Note}

Springer Nature remains neutral with regard to jurisdictional claims in published maps and institutional affiliations.

Ready to submit your research? Choose BMC and benefit from:

- fast, convenient online submission

- thorough peer review by experienced researchers in your field

- rapid publication on acceptance

- support for research data, including large and complex data types

- gold Open Access which fosters wider collaboration and increased citations

- maximum visibility for your research: over $100 \mathrm{M}$ website views per year

At BMC, research is always in progress.

Learn more biomedcentral.com/submissions 